\title{
PERIODIC STRUCTURE IN "SONG OF MYSELF"
}

\author{
Ken EgAN, JR.
}

"SONG OF MYSELF" alternates between expansion and contraction of consciousness. The expansive catalogues dissolve the subject-object division as the persona merges with the phenomenal world. These sections of release are punctuated by sections of declaration that sum up the psychic gains of expansion, an alternating pattern that creates a cycle of release and control for both persona and reader. Through this periodic structure the poem's two essential themes unfold: the persona's evolution toward an integrated personality, and the reader's necessary involvement in that process.

The alternating pattern in "Song of Myself" should be understood first as a recurring motif in Whitman's poetry, and then more broadly, as a recurring motif in literature of the American Renaissance. F. O. Matthiessen has given a definitive account of Whitman's "organic" or "rhythmic" poetic. Discussing the poet's fascination with opera, Matthiessen observed:

Whitman's analogy of his form with music escaped being just a made-up notion precisely to the extent to which his responses to the opera instructed him in the physical basis of rhythm. It is palpable ... that our conventional poets believed that the source of poetry was in England, and behaved as though rhythm was a matter of instructed imitation. The followers in this country of Byron and Keats had shown no more realization than our preceding century of followers of Pope that poetic rhythm was an organic response to the centers of experience-to the internal pulsations of the body, to its external movements in work and in making love, to such sounds as the wind and the sea. ${ }^{1}$

While the critic is interested primarily in meter, there is no question that Whitman's sensitivity to "the internal pulsations of the body" had farreaching consequences for his poetry. That influence is most apparent in a poem like "As I Ebb'd with the Ocean of Life," with its controlling metaphor of the ebbing and flowing of consciousness. In "Song of Myself" there are a variety of rhythmic alternations: between Spirit and Matter, between virtue and vice, between the one and the many. These alternations, however, are subsumed under the more pervasive alternation between expansion and contraction of the persona's consciousness. We discern this fundamental alternation on a microcosmic scale in individual "stanzas." The passage describing the persona's identification with the sea evokes this sense of rhythm, of movement in and out, of withdrawal and return: 
Sea of stretched ground-swells!

Sea breathing broad and convulsive breaths!

Sea of the brine of life! Sea of unshovelled and alwaysready graves!

Howler and scooper of storms! Capricious and dainty sea!

I am integral with you. . . . I too am of one phase and of all phases. ${ }^{2}$

The opera initiates a similar shuttling back-and-forth between far-flung and localized experiences:

I hear the trained soprano. ... she convulses me like the climax of my love-grip;

The orchestra whirls me wider than Uranus flies,

It wrenches unnamable ardors from my breast,

It throbs me to gulps of the farthest down horror,

It sails me. . . . I dab with bare feet. . . . they are licked by the indolent waves, ... (11. 602-606)

On a broader scale, this rhythmic alternation is a structural principle of the entire poem. ${ }^{3}$ Sections $1-7,17-25$, and 44-52 consist primarily of direct assertions. These sections are distinguished by declarative sentences, usually with " $\mathrm{I}$ " in the subject position, followed by a verb of thought or belief and an abstract noun functioning as object. These epigrammatic sections are metapoetic, dominated by statements about poetry and the Self. Sections 8-16 and 26-43 consist primarily of catalogues. Style in these sections contrasts sharply with the syntactical and cognitive propriety of the declarative sections. Sentences center on the "to be" verb or, more typically, disrupt standard prose syntax altogether by inserting run-on fragments. We might say that the declarative (contracting) sections supply a conservative backbeat for the outlandish, radical sections of expansion.

Rhythmic patterning in "Song of Myself" is analagous to the rhythmic psychology of Emerson and the rhythmic cosmology of Poe. Here we come face-to-face with a figure of speech so culturally pervasive that participants in that culture, despite essential differences in belief, unconsciously use that figure. Hayden White has discussed the role of such figures of speech in nineteenth-century history writing. He distinguishes among four types of tropes: Metaphor, Metonymy, Synecdoche, and Irony. The first three tropes are defined as "paradigms of explanation," or bases for explaining society and world; Irony, on the other hand, denies language's explanatory power. ${ }^{4}$ The figure of rhythm or periodicity is an example of Metaphor as it establishes a likeness between cosmic-psychological processes and natural rhythms and so provides a "paradigm of explanation" for its users. More specifically, the rhythmic metaphor of the American romantics bears crucial similarities to the organic metaphor of the eighteenth-century German philosopher Herder. Responding to the mechanistic historiography of the eighteenth cen- 
tury, Herder affirmed "the Metaphorical identification of the doctrine of Providence with the life of the plant, which permits the ordering of the story material into a typical Comedy." 5 We can point to Herder, then, as one of the "sources" of this dominant metaphor, anticipating as he does the work of Coleridge and Carlyle, those more immediate influences on the American Renaissance.

We will hardly be surprised to discover so essential a correspondence between the work of Whitman and that of his "master," Emerson. Emerson was endlessly fascinated by what he saw as the "alternating" pattern of consciousness. This fascination is most clearly articulated in a passage from his fournals dated June (?) 1838:

Alternation: the Bath \& the Battle of Pisa as drawn by Michel Angelo, exhibited the extremes of relaxation \& strength. We like the girding belt; we like to be dissolved in liberty. When we have seen friends \& talked for days until we are turned inside out, then go lie down, then lock the study door; shut the shutters, then welcome falls the imprisoning rain, dear hermitage of nature. Recollect the spirits. Close up the too expanded leaves. ${ }^{6}$

The temperamental differences between Whitman and Emerson are evident when this entry is placed beside "Song of Myself"; Emerson's more introverted, even dour personality reveals itself. Still, the tonal differences cannot obscure the essential similarity in metaphor. Emerson's reference to closing up "the too expanded leaves" is especially apt when considering Whitman's poem. After all, for Emerson and Whitman alike, the individual consciousness cannot simply "dissolve"; to dissolve completely is to lose consciousness, to cease to be a "self." Those sections of declaration are crucial for "re-collecting" the spirits, for tallying the gains of the expansive sections. Neither "relaxation" nor "strength" suffices in isolation if one is to be an integrated personality.

The essay "Circles" extends the theme of alternation but stresses the dynamic interaction between restraint and growth. Arguing that the circle is the fundamental metaphor for all experience, Emerson describes the expansive self as a series of larger circles. These expansions meet two primary checks, however: constraining ideas and external circumstance. Selfexpansion must first meet these checks, then push beyond them:

The extent to which this generation of circles, wheel without wheel, will go, depends on the force or truth of the individual soul. For it is the inert effort of each thought, having formed itself into a circular wave of circumstance, -as for instance an empire, rules of an art, a local usage, a religious rite, - to heap itself on that ridge and to solidify and hem in the life. But if the soul is quick and strong it bursts over that boundary on all sides and expands another orbit on the great deep, which also runs up into a high wave, with attempt again to stop and to bind. ${ }^{7}$

Rather than a static cycle, then, alternation appears an evolutionary process of push and shove, a truly "pulse-like" development. 
Poe's Eureka provides an even more fascinating analogue for "Song of Myself," for there are surprising similarities between these two "antithetical" poets. Concluding his analysis of "Attraction" and "Repulsion" as fundamental principles, Poe asserts:

Guiding our imaginations by that omniprevalent law of laws, the law of periodicity, are we not, indeed, more than justified in entertaining a belief-let us say, rather, in indulging a hope-that the processes we have here ventured to contemplate will be renewed forever, and forever, and forever: a novel Universe swelling into existence, and then subsiding into nothingness, at every throb of the Heart Divine?

And now - this Heart Divine - what is it? It is our own. ${ }^{8}$

Not only does Poe anticipate Whitman's universal sense of organic rhythm, but he directly connects that rhythm to bodily functions. Thus we could group Poe with those American writers who resist the British models of meter Matthiessen discusses. In another passage, Poe seems to build upon Emerson's alternating psychology in constructing his own cosmic scheme:

... just as it is in your power to expand or to concentrate your pleasures (the absolute amount of happiness remaining always the same) so did and does a similar capability appertain to this Divine Being, who thus passes his Eternity in perpetual variation of Concentrated Self and almost Infinite Self-Diffusion. What you call The Universe is but his present expansive existence. He now feels his life through an infinity of imperfect pleasures - the partial and painintertangled pleasures of those inconceivably numerous things which you designate as his creatures, but which are really but infinite individualizations of Himself. ${ }^{9}$

The obvious similarities between Whitman's and Poe's descriptions of experience allow us to perceive more fully the crucial differences in belief. These differences will in turn highlight the connection between periodic structure and the persona's development in "Song of Myself." First, Whitman would deny Poe's hierarchy of God and individual self, declaring that "Walt Whitman" is a "kosmos," an equal to God. This is another way of stating the familiar argument that while Poe is a Neoplatonic writer, analyzing the relationship between macrocosmic universe and microcosmic self, Whitman is a Transcendentalist who sees the Self identified with God. Further, the process of expansion or "dispersion" that terrifies Poe exhilarates Whitman's persona; in "Song of Myself" the expansive catalogues, in which the persona dissolves into an astounding range of particulars, are the heights of consciousness.

Most importantly, for Whitman the "omniprevalent law of laws, the law of periodicity" is not simply cyclical, but dialectical, leading through an upward spiral to higher stages of consciousness. The rhythmic alternations in "Song of Myself" progress toward more ambitious projections of the Self and more exalted declarations of faith. Thus, the analogy to "Circles" takes on added meaning. For example, the assertions in the first seven sections are 
muted by comparison with the prophetic tone of the last eight sections. Compare the following two passages:

\section{I celebrate myself,}

And what I assume you shall assume,

For every atom belonging to me as good belongs to you. (ll. 1-3)

Why should I wish to see God better than this day?

I see something of God each hour of the twenty-four, and each moment then,

In the faces of men and women I see God, and in my own face in the glass;

I find letters from God dropped in the street, and every one is signed by God's name,

And I leave them where they are, for I know that others will punctually come forever and ever. (11. 1276-1280)

Read in light of the last eight sections, the opening appears a tentative assertion of faith, as yet untested, that grows in firmness and reach. The casual, somewhat cocky tone of the poem's opening is replaced by an almost breathless attempt to encapsulate the persona's discoveries. "Song of Myself" is by no means an isolated example of this dialectical growth in Whitman's poetry. "Crossing Brooklyn Ferry" exemplifies the same pattern on a smaller scale. The confident but low-key assertions of the first part expand and swell in the course of the poem, moving toward the summary cataloguing and fervid assertions of section nine.

The drama of Self-discovery unfolds side-by-side with the drama of reader-persona engagement. Much of the best recent criticism on "Song of Myself" has focused on this second drama. ${ }^{10}$ The poem suggests at least two motives for this fascination with the reader. First, the persona desires to bring the reader along on the "journey" described so vividly at the poem's conclusion. The persona-reader relationship can be seen as a special case of the Self's engagement with the Not-Me, special because the reader is a sentient observer who can duplicate the experience of the persona. If the Self functions to draw out the optimum significance of each particle of matter, then the Self has a unique obligation toward the reader: it must reach beyond identification to inspiration. The second, more immediate rhetorical problem is how to break through the reader's aesthetic norms to gain toleration for this radically new American poetic. Here we are probably safe in speaking of both Whitman the poet and "Whitman" the persona's rhetorical problem. Thus the poem's rhetoric should not be separated from the rhetoric of the 1855 "Preface," which makes a plea for the poem's acceptance. ${ }^{11}$ In sum, the rhythmic alternation of expansion (through catalogues) and contraction (through declaration), so crucial to the persona's psychological evolution, serves the rhetorical function of demonstrating and explaining.

The catalogues demonstrate by plunging the reader into the heightened 
sensibility of the Transcendental Everyman. They are demonstrations of Emersonian Reason in operation, as proof to the "eleve." The persona stops talking about the process of identification and begins to live it out, to experience it. The catalogues are both vivid in detail and massive in geographic and social scale, ranging from city, to farm, to wilderness, and again, ranging through all occupations and races. John B. Mason has offered an ingenious explanation of how these catalogues involve the reader in Self-realization. Using an analogy to film, Mason explains that "the reader, through a process of skimming and condensation, forms a single image of each catalogue and finally a single image of that unnameable reward which awaits the poet and the reader." 12 While not entirely persuaded that the reader carries out this summing up process, I am convinced by Mason's assertion that the reader is lured into an experience of the ineffable. That is, the reader is urged to make a leap of faith; the overwhelming surge of mergings masters conscious control (i.e., "Understanding"), forcing the reader into a trancelike apprehension of the perpetual flow of Being. Of course the persona takes a terrible chance here as the intended trancelike effect might collapse into boredom and indifference. The alternating structure of the poem provides the reader multiple opportunities to make this leap of faith as the voice shifts from expansive catalogue to "girded" declaration, then back to even more ambitious projections, as though the persona were teasing the reader into release.

The sections of contraction - sections $1-7,17-25$, and 44-52-provide a psychological relief, a closing up of "the too expanded leaves," for the reader as well as the persona. Moreso, these sections serve the second rhetorical task, that of breaking down the reader's resistance to a new poetic. We can detect an evolving relationship between persona and reader, a development from wary distrust to affectionate embrace. In the first part of the poem the persona is assertive, combative, deeply aware of the nay-sayers. As an initiating movement it dismisses the negative influences - the socialites, the academics, the businessmen, all emissaries of Understanding - and advocates activation of the senses of Reason. Here, then, the persona is deeply divided in his response to the reader. On the one hand, the reader is bluntly informed that "what I assume you shall assume," and again, "Stop this day and night with me and you shall possess the origin of all poems." These addresses can be read as positive assertions of comradery, but the preemptory tone implies a suppressed doubt about the reader's allegiance. In the second phase of contraction (sections 17-25), the persona's attitude toward the reader is decidedly less guarded, less self-conscious, and more intimate. While there is still plenty of bravura and puffery, also evident here is a conciliatory tone. So section 17 begins: "These are really the thoughts of all men in all ages and lands, they are not original with me, / If they are not yours as much as mine they are nothing, or next to nothing" (11. 355-356). But the essential statement of the persona's rhetorical stance comes in section twenty-two: "Evil propels me, and reform of evil propels me... I stand indifferent, / My gait is 
no faultfinder's or rejector's gait" (11. 470-471). This passage suggests a speaker grown confident enough in his own capacities to step beyond polemics and backbiting.

Section forty-eight initiates the poem's formal conclusion as the persona pulls together the threads of belief into a program of action for the reader. The tone becomes one of poised confidence. The truths of Being and identity are now "self-evident"; these have been asserted and demonstrated in the preceding parts. The primary task becomes preparing the reader for the next release, the next stage of expansion: "The past and present wilt. . . . I have filled them and emptied them, / And proceed to fill my next fold of the future" (11. 1309-1310). The poem actually projects beyond itself into the reader's living, day-to-day experience. The persona imagines the Self's final and complete merging with Being as through death it enters into the grass. The reader is projected not only into the future, but into space, into a journey, in search of the now literally diffused speaker of the poem:

Failing to fetch me at first keep encouraged,

Missing me one place search another,

I stop some where waiting for you (11. 1334-1336)

Thus this poem of alternation, of dialectical unfolding, concludes with a beginning, preparing the way for the next stage of expansion. In this sense, "Song of Myself" has no ending at all. As Emerson affirmed: "Our life is an apprenticeship to the truth that around every circle another can be drawn; that there is no end in nature, but every end is a beginning; that there is always another dawn risen on mid-noon, and under every deep a lower deep opens." 13

Rocky Mountain College

\section{NOTES}

1 F. O. Matthiessen, American Renaissance: Art and Expression in the Age of Emerson and Whitman (New York: Oxford University Press, 1941), 564.

2 Walt Whitman's Leaves of Grass: The First (1855) Edition, Malcolm Cowley, ed. (New York: Viking, 1959), 11, 457-461. All further references to this edition appear in the text. Although the section numbers do not appear until later editions, I have used them here to simplify the discussion of structure.

3 Previous analyses of structure closely related to my own include Alfred S. Reid, "The Structure of 'Song of Myself' Reconsidered," Southern Humanities Review, 8 (1974), 597-614, which divides the poem along similar lines but focuses exclusively on the evolution of Self; John B. Mason, "Walt Whitman's Catalogues: Rhetorical Means for Two Journeys in 'Song of Myself," American Literature, 45, 1 (March 1973), 34-49, which discusses the simultaneous unfolding of Self and persona-catalogues; and Howard J. Waskow, in Whitman: Explorations 
in Form (Chicago: University of Chicago Press, 1966), 156-189, which provides a more comprehensive reading of the poem than the previous two analyses but does not account for the poem's periodic structure.

4 Hayden White, Metahistory: The Historical Imagination in Nineteenth-Century Europe (Baltimore: Johns Hopkins University Press, 1973), 36-37.

5 White, 79.

6 A. W. Plumstead and Harrison Hayford, eds., The fournals and Miscellaneous Notebooks of Ralph Waldo Emerson, Vol. VII: 1838-1842, (Cambridge: Belknap, 1969), 20.

7 Ralph Waldo Emerson, Essays, First Series (Boston: Riverside Press, 1903), 304.

8 Edgar Allan Poe, Eureka: A Prose Poem (New York: Putnam, 1848), 139.

9 Eureka, 142.

10. See Bernard Cohen, "Song of Myself': Enticement to Faith as Knowledge," American Transcendental Quarterly, 12 (Fall 1971), 49-54; Diane Kepner, "From Spears to Leaves: Walt Whitman's Theory of Nature in 'Song of Myself," American Literature, 51, 2 (May 1979), esp. $202 \mathrm{ff}$; and John B. Mason, "Questions and Answers in Whitman's 'Confab," American Literature, 51, 4 (January 1980), 493-506.

11 I am indebted for this observation to Chaviva Hosek, "The Rhetoric of Whitman's 1855 Preface to Leaves of Grass," Walt Whitman Review, 25, 4 (December 1979), 163-173.

12 Mason, "Walt Whitman's Catalogues," 49.

13 Emerson, "Circles," 301. 